\section{FITZPATRICK VERSUS SMITH.}

To the Editor of THE LANCET.

SIR,-In the report of the case Fitzpatrick $v$. Smith, lately tried before Vice-Chancellor James, which appears in your last number, there are so many fallacies calculated to mislead the judgment of my professional brethren, to operate so injuriously upon my interests through prejudice on the part of the public, and throw such serious discredit upon myself, that I must ask you, in the cause of justice, and for my protection, to make the following correction in the same prominent manner as that in which the erroneous report has been put. Several minor inaccuracies I omit to notice.

It is not true that $D_{1}$. Smith entered into an agreement with me to act as a physician at Seaforth, the fact being that he, on the 11th of March, 1867, became my assistant, under a written agreement, " to perform the duties of visiting, dispensing, and keeping my books, subject to $\mathrm{my}$ approval;" and by the same agreement it was declared "lawful for me at any time to give him three months notice to put an end to the aforesaid agreement if he failed, neglected, or refused to perform the above-named duties." In consequence of his "failing and neglecting" to perform his duties to my satisfaction, I, on the 24th of February, 1868, gave him three months' notice in writing to determine his engagement; and a few days afterwards I gave him another notice, one of immediate dismissal, in consequence of "insolent behaviour and disgraceful conduct" to myself personally in my surgery. The eleventh clause of the agreement between myself and the defendant provides that, " in case the said Charles Swaby Smith should cease to be my assistant, he should not practise within five miles of my residence for a term of ten"years." I distinctly deny that I ever wrote, spoke, or implied that "I had put an end to the agreement without cause, and now seek to put the agreement into force to restrain the defendant from practising in my neighbourhood."

I lost my suit by reason of a fatal defect in the bill of complaint filed in this case, wherein the notice of the 24th of February, determining the defendant's engagement in three months, as well as the reasons for giving this notice. were entirely and erroneously omitted. The notice of immediate dismissal in consequence of "insolent behaviour and disgraceful conduct" was inserted and relied upon in the bill of complaint. 'The former contingency (that of failure or neglect of duty) was contemplated and provided for in the agreement, but omitted in the bill ; the latter was not either contemplated or provided for in the agreement, but was inserted and relied upon in the bill. Hence the failure of $\mathrm{my}$ suit.

I am, Sir, your obedient servant,

Cornelius Donovan Fitzpatrick.

Litherland-park, Liverpool, Feb. 15th, 1869.

\section{H E A T T O F S E A M N. To the Editor of The LaNCET.}

SiR,-Under the above heading, in The Lancet of Feb.6th, I was pleased to see your allusion to the conviction by the Hull stipendiary magistrate of the master of a vessel for proceeding to sea without a due supply of medical stores \&c. ; also your pertinent remarks on the insufficiency of guarantee existing that the provisions of the Act on this point are effectively carried out.

I believe there never has been an Act of Parliament framed in England that did not leave a convenient back door for the express use and convenience of those who are desirous of evading in some respect its enactments. In February last, in a letter to Mr. Cave relating to the Duke of Richmond's Act, I pointed out the necessity of someone being deputed officially to inspect all medical stores prior to shipment, and suggested that the duty should devolve on the inspector of seamen for the port, who should, on the completion of a medicine chest by the shipping druggist, inspect the same, and give a certificate to the effect that such chest for such ship was fitted according to the Government scale; that this certificate would be a protection to captains and owners of vessels, and a full answer to the allegations that are too frequently made by sailors to the consuls of foreign ports that during the voyage they were deficient of medical stores.

Why an Act of Parliament should be so framed as to admit of its provisions being carried out or not at the caprice of masters of vessels I am at a loss to understand. In France they do these things better than in England. There is no such word as "may" in French legislature. "May have their men inspected"- such, I believe, are the words of the present Mercantile Marine Act of England. "Must," methinks, is a word that would be more conducive to the well-doing and efficiency of our merchant navy. As you justly observe, it is useless legislating without due provision is made that the law shall be obeyed.

As regards the "inspection of seamen," I have already on a former occasion, in your valuable journal, made the public acquainted with my views of the advantages to be gained by making the clause relating to the subject imperative. The due supply of good lime-juice is no doubt a step in the right direction, but alone it is no antidote for the evils that are so patent to the practised eye. The remedy for increasing and promoting the physique of our merchant sailors isthe immediate extension of the Contagious Diseases Act to all ports, and the medical inspection of all crews prior to shipment. I am, Sir, your obedient servant,

F. J. SANDFORD, late R.N.

Late Surgeon-Superintendent, Seamen's Hospital, and Inspector for the Board of Trade, Cardiff.

Bernard-street, Russell-square, Feb. 10th, 1869.

\section{THE POOR-LAW MEDICAL SERVICE.}

\section{To the Editor of THE LANCET.}

SrR,-I beg to forward you a copy of a memorial which will, I understand, be sent in the course of next week to the Poor-law Board, protesting against the extraordinary proposition recently adopted by a majority of the Birmingham guardians, to reduce the number of their district medical officers from eight to five; and, judging from the long list of physicians, surgeons, and general practitioners who have already signed, it is evident that the resolution has met with general condemnation from the profession of that town. Whilst the action of the medical gentlemen practising in Birmingham in thus unitedly combining to express their disapproval of this step on the part of the local board cannot be too highly commended, as evidencing a growing disposition to support the claims of the Poor-law Medical Service, I consider it but right that the profession should be made acquainted with the fact that the resolution to diminish the medical facilities of the poor of this town, and to dismiss three unoffending medical officers, was urged by and carried through the influence of a medical guardian, who moved the appointment of a committee to consider the question of medical relief, with power to call before them the medical and relieving officers; and which did not call one, but brought up a report with a resolution to reduce the staff, so that in future each medical officer would have a district containing a population of about 44,000 , the legal limit being, as you are aware, 15,000 .

The guardian of the poor who has thas distinguished himself is John Clay, Esq., Professor of Midwifery at Queen's College, Birmingham; and the other members of the board assure the medical officers that they have no one to thank for this but Mr. John Clay.

Dean-street, Feb. 17th, 1869

$$
\text { I am, Sir, yours obediently, }
$$

JOSEPH ROGERS.

$$
\text { The memorial is as follows :- }
$$

\section{To the President of the Poor-law Board.}

Birmingham, January 27 th, 1869.

Mr LORD,-We, the physicians and surgeons of the public institutions and general practitioners of Birmingham, seeing that the board of guardians of the parish of Birmingham have resolved to reduce the nu-nber of the parochial medical officers from eight to five, respectfully request you at once to make such public inquiry, on oath, as will prevent such an injustice to the poor of this parish. Taking into consideration the fact that the number of the inhabitants of the parish is upwards of 220,000 , we are of opinion the number of medical officers is not at present at all too many to properly perform the work incident to so large a popula- 